\title{
Effect of polyethylene cross-linking on properties of foams
}

Wojciech Głuszewski, Andrzej Stasiek, Aneta Raszkowska-Kaczor, Daniel Kaczor

\begin{abstract}
The process of cross-linking of polyethylene using gamma radiation $(\gamma)$ and electron beam (EB) was tested from the point of view of density of foam. Particular attention was paid to the postradiation oxidation effect of the polymers. The study used two types of radiation sources of varying dose rates: gamma radiation $(4 \mathrm{kGy} / \mathrm{h})$ and $\mathrm{EB}(14000 \mathrm{kGy} / \mathrm{h})$. Radiolysis studies of the polymers used the radiation yield of hydrogen evolved $\left(G_{\mathrm{H}_{2}}\right.$, approximately proportional to the number of radicals) and radiation yield of oxygen absorbed by the polymer $\left(G_{\mathrm{O}_{2}}\right)$. Oxidation of polymer due to radiation was also evaluated using diffuse reflectance spectroscopy.
\end{abstract}

Keywords: polyethylene foam $\bullet$ radiation cross-linking $\bullet$ postradiation oxidation

\author{
W. Głuszewski ${ }^{凶}$ \\ Institute of Nuclear Chemistry and Technology \\ 16 Dorodna St., 03-195 Warsaw, Poland \\ E-mail: w.głuszewski@ichtj.waw.pl
}

\section{A. Stasiek, A. Raszkowska-Kaczor}

Institute for Engineering of Polymer Materials and Dyes 55 M. Skłodowskiej-Curie St., 87-100 Toruń, Poland

\section{Kaczor}

Faculty of Chemistry

Nicolaus Copernicus University

7 Gagarina St., 87-100 Toruń, Poland

Received: 13 November 2017

Accepted: 20 April 2018

\section{Introduction}

Cross-linked polyethylene foams are characterized by good thermal insulation properties, low density, low thermal conductivity, high sound absorption, and chemical resistance [1]. These properties cause their widespread use in the construction, automotive, and packaging industries, as well as in sports [2]. The process for preparing chemically/irradiation cross-linked foams consists of the following steps: preparation of powder mixtures, pellet extrusion, film extrusion, and foaming of the cross-linking materials $[3,4]$. This study compared the process of polyethylene cross-linking using gamma radiation $(\gamma)$ and electron beam (EB) from the point of view of density of the resulting foam. The main difference in the radiation treatment of polymers was the use of different power doses [5]. In the case of gamma radiation, the dose rate was $\sim 4 \mathrm{kGy} / \mathrm{h}$ and, for an EB, the dose rate was $\sim 14000 \mathrm{kGy} / \mathrm{h}$. The method of radiation is important from the point of view of the processes of postradiation oxidation of polymer. In general, we can assume that the formation of cross-links competes with the reactions of free radicals with oxygen. The more cross-linked the polyethylene is, the lower is the density of the foam that we obtain. 
Table 1. Composition of samples used in tests

\begin{tabular}{|c|c|c|c|c|c|}
\hline \multirow{2}{*}{$\begin{array}{l}\text { Sample } \\
\text { no. }\end{array}$} & \multirow{2}{*}{$\begin{array}{l}\text { Name of agent affecting } \\
\text { radiation cross-linking }\end{array}$} & \multicolumn{4}{|c|}{ Composition [\%] } \\
\hline & & $\begin{array}{l}\text { Agent affecting radiation } \\
\text { cross-linking }\end{array}$ & $\begin{array}{c}\text { Porophor } \\
\text { content }\end{array}$ & Antioxidant & Polyethylene \\
\hline 1 & & 1 & 15 & 0.2 & 83.8 \\
\hline 2 & Zinc oxide & 3 & 15 & 0.2 & 81.8 \\
\hline 3 & & 5 & 15 & 0.2 & 79.8 \\
\hline 4 & & 1 & 15 & 0.2 & 83.8 \\
\hline 5 & Tracryl & 3 & 15 & 0.2 & 81.8 \\
\hline 6 & & 5 & 15 & 0.2 & 79.8 \\
\hline 7 & & $0.5 / 0.5$ & 15 & 0.2 & 83.8 \\
\hline 8 & & $0.7 / 0.3$ & 15 & 0.2 & 83.8 \\
\hline 9 & Zinc oxide and tracryl & $0.3 / 0.7$ & 15 & 0.2 & 83.8 \\
\hline 10 & Zinc oxide and tracryı & $1.5 / 1.5$ & 15 & 0.2 & 81.8 \\
\hline 11 & & 2/1 & 15 & 0.2 & 81.8 \\
\hline 12 & & $1 / 2$ & 15 & 0.2 & 81.8 \\
\hline
\end{tabular}

\section{Materials}

The polyethylene used was low-density polyethylene (LDPE) (type Malen E FGAN 23-D003, from Lyondellbasell): density $-0.922 \mathrm{~g} / \mathrm{cm}^{3}$ and melt flow rate (MFR) $(190 \mathrm{C} / 2.16 \mathrm{~kg})-0.31 \mathrm{~g} / 10 \mathrm{~min}$. Azodicarbonamide (type Unicell D1500TSK, from Tramaco) was used as a foaming agent. Other components used were zinc oxide, zinc stearate, Tracryl PO 3501, and Irganox PS 802 FL (Ciba Specialty Chemicals) (Table 1). All components of the mixture were in the form of powders.

All mixtures were thrown into a mixer and stirred for $5 \mathrm{~min}$ at $40^{\circ} \mathrm{C}$ at $75 \mathrm{rpm}$. Extrusion of the pellets required to produce the film was carried out using a twin-screw extruder with screw configuration K3. The temperature profile along the barrel was 100 , $110,110,115$, and $125^{\circ} \mathrm{C}$. The polymer film was obtained using the laboratory equipment consisting of the single-screw extruder (type Plasti-Corder PLV 151; Brabender) with a flat die and polishing rolls. The screw parameters were as follows: working length $25 \mathrm{D}$ and compression ratio $3: 1$. The experimental stand was equipped with a device for measuring the temperature of the heating zone of the plasticizing system and the head. The screw rotation speed was $75 \mathrm{rpm}$. The temperature profile along the barrel was $100,110,125$, and $125^{\circ} \mathrm{C}$. The foaming process was conducted in a silicone oil bath at $225^{\circ} \mathrm{C}$ for $1.5 \mathrm{~min}$.

\section{Irradiation}

In order to evaluate the effect of oxygen diffusion within polymers on postradiation oxidation processes, radiation sources with different dose rates were used. The electron accelerator Elektronika $10 / 10$ with energy of $10 \mathrm{MeV}$ and with beam power of $10 \mathrm{~kW}(14000 \mathrm{kGy} / \mathrm{h})$ was used in this study. For comparison, we also conducted a radiation treatment using gamma irradiation with an average energy of $1.25 \mathrm{MeV}$ and dose rate of $4 \mathrm{kGy} / \mathrm{h} \mathrm{[6].}$ Samples were irradiated in air at ambient temperature. The analyses were performed immediately after irradiation.

\section{Gas chromatography}

A gas chromatograph (Shimadzu; thermal conductivity detector, molecular sieve: $5 \AA$ ) was used for the determination of radiation yield of hydrogen evolution $\left(G_{\mathrm{H}_{2}}\right)$ and that of absorption of oxygen $\left(-G_{\mathrm{O}_{2}}\right)$ from the dose of radiations in the range of $5-20 \mathrm{kGy}$. Samples were irradiated in air, in closed vessels, with the gas phase subjected to gas chromatography (GC) analysis at room temperature [7].

By adopting a simplified model in which the number of radicals is double the hydrogen yield, we can estimate the cross-linking efficiency using the following formula:

$$
G_{\text {cross }}=\left(2 G_{\mathrm{H}_{2}}-G_{\mathrm{O}_{2}}\right) / 2
$$

We assume that radicals that react with oxygen do not participate in the cross-linking process. The calculation results are shown in Table 2.

\section{Total density}

The main goal of the research was to determine the influence of postradiation processes of polymer oxidation (different irradiation times) on the properties of foams. Total apparent density $\left(\rho_{a}\right)$ was determined from the cross-linked and foamed samples. Three samples of each film were studied. The dimension of the samples was approximately $50 \times 50 \mathrm{~mm}$. Overall dimensions of the samples were measured in accordance with European standards.

\section{Scanning electron microscopy analysis}

Scanning electron microscopy (SEM) analysis was performed with a scanning electron microscope (Hitachi SU8010, Japan, 2011) equipped with a Cressington (Germany, 2011) sputter coater module that measures the thickness of the sputtered gold layer. The microscope is equipped with a cold cathode field emitter, secondary electron (SE) and back-scattered electron (BSE) detectors, and energy-dispersive X-ray (EDX) detector for X-ray microanalysis. 
Table 2. Densities of the foams produced from the cross-linked polyethylene

\begin{tabular}{|c|c|c|c|c|c|c|c|c|c|}
\hline \multirow{4}{*}{$\begin{array}{c}\text { Sample } \\
\text { no. }\end{array}$} & \multicolumn{4}{|c|}{ Density $\left(\rho_{a}\right)$} & \multirow{2}{*}{\multicolumn{2}{|c|}{$\rho_{a}(\gamma / \mathrm{EB})$}} & \multirow{3}{*}{\multicolumn{2}{|c|}{$\begin{array}{c}G_{\text {cross }} \\
{[\mu \mathrm{mol} / \mathrm{J}]}\end{array}$}} & \multirow{4}{*}{$\begin{array}{c}G_{\text {cross }} \\
(\mathrm{EB} / \gamma)\end{array}$} \\
\hline & \multicolumn{2}{|c|}{$\mathrm{EB}$} & \multicolumn{2}{|c|}{$\gamma$} & & & & & \\
\hline & \multicolumn{4}{|c|}{ Dose [kGy] } & \multicolumn{2}{|c|}{ Dose [kGy] } & & & \\
\hline & 60 & 100 & 60 & 100 & 60 & 100 & $\mathrm{~EB}$ & $\gamma$ & \\
\hline 1 & 0.22 & 0.13 & 0.58 & 0.47 & 2.64 & 3.62 & 0.30 & 0.21 & 1.43 \\
\hline 2 & 0.23 & 0.17 & 0.30 & 0.23 & 1.30 & 1.35 & 0.26 & 0.23 & 1.13 \\
\hline 3 & 0.22 & 0.10 & 0.34 & 0.22 & 1.55 & 2.20 & 0.26 & 0.23 & 1.13 \\
\hline 4 & 0.09 & 0.08 & 0.15 & 0.36 & 1.67 & 4.50 & 0.36 & 0.19 & 1.89 \\
\hline 5 & 0.37 & 0.45 & 0.49 & 0.28 & 1.32 & 0.62 & 0.34 & 0.18 & 1.89 \\
\hline 6 & 0.41 & 0.41 & 0.58 & 0.33 & 1.41 & 0.80 & 0.27 & 0.18 & 1.50 \\
\hline 7 & 0.17 & 0.22 & 0.11 & 0.24 & 0.65 & 1.09 & 0.29 & 0.22 & 1.32 \\
\hline 8 & 0.24 & 0.08 & 0.19 & 0.18 & 0.79 & 2.25 & 0.24 & 0.19 & 1.26 \\
\hline 9 & 0.09 & 0.10 & 0.28 & 0.26 & 3.11 & 2.60 & 0.38 & 0.21 & 1.81 \\
\hline 10 & 0.11 & 0.06 & 0.56 & 0.27 & 5.09 & 4.50 & 0.33 & 0.16 & 2.06 \\
\hline 11 & 0.09 & 0.04 & 0.38 & 0.60 & 4.22 & 15.00 & 0.33 & 0.24 & 1.38 \\
\hline 12 & 0.08 & 0.08 & 0.54 & 0.68 & 6.75 & 8.50 & 0.26 & 0.19 & 1.37 \\
\hline
\end{tabular}

Notes: Doses: 60 and $100 \mathrm{kGy}$. For cross-linking, we used an electron beam (EB; $14000 \mathrm{kGy} / \mathrm{h})$ and gamma radiation (4.0 kGy/h).

\section{Diffuse reflectance spectroscopy}

One of the advantages of diffuse reflectance spectroscopy (DRS) is the possibility of investigating polymers in any shape [8]. The principle of measurement consists in directing the beam of analysing light on the surface of the sample. Part of the light is reflected back unchanged, but another part is bent into the sample and, after reflections inside, leaves the sample with spectral information about the compounds formed as the result of irradiation and/or the compounds present before irradiation and destroyed thereafter. In our investigations, the spectrophotometer JASCO V-670 equipped with a reflection device was used $[9,10]$. Several bands of absorption were identified. The band around $210 \mathrm{~nm}$ is ascribed to peroxide groups. Bands at $295-320 \mathrm{~nm}$ are ascribed to CO groups at the end of chains (products of degradation), and peaks in the range of 245 are ascribed to carboxyl groups in the middle of polymer chains [11].

\section{Results}

Table 3 shows the performance in terms of evolved hydrogen and absorbed oxygen during the two modes of radiation: gamma rays $(4 \mathrm{kGy} / \mathrm{h})$ and $\mathrm{EB}$ $(14000 \mathrm{kGy} / \mathrm{h})$. They are listed here with the density of cross-linked foams obtained on using gamma radiation and $\mathrm{EB}$.

In the case of foams cross-linked with gamma radiation ( 60 and $100 \mathrm{kGy}$ ), the densities were higher than those obtained for foams cross-linked with electron radiation. This confirms the assumption that by limiting the diffusion of oxygen into the polymer (high dose rate), the efficiency of cross-linking processes can be increased. The lowest density was $0.18 \mathrm{~g} / \mathrm{cm}^{3}$, obtained for a sample obtained from a mixture containing zinc oxide and Tracryl in the ratio $0.7 / 0.3$. The highest density value $\left(0.68 \mathrm{~g} / \mathrm{cm}^{3}\right)$ was obtained for Sample 12 (ratio of zinc oxide and Tracryl: $1 / 2$ ).
Table 3. Radiation performance in terms of evolution of hydrogen and oxygen uptake for the different samples on using electron beam (EB) and $\gamma$ irradiation for cross-linking

\begin{tabular}{ccccc}
\hline \multirow{2}{*}{$\begin{array}{c}\text { Sample } \\
\text { no. }\end{array}$} & \multicolumn{2}{c}{ EB } & \multicolumn{3}{c}{ Gamma radiation $(\gamma)$} \\
\cline { 2 - 5 } & $\begin{array}{c}G_{\mathrm{H}_{2}} \\
{[\mathrm{mmol} / \mathrm{J}]}\end{array}$ & $\begin{array}{c}G_{\mathrm{O}_{2}} \\
{[\mathrm{mmol} / \mathrm{J}]}\end{array}$ & $\begin{array}{c}G_{\mathrm{H}_{2}} \\
{[\mathrm{mmol} / \mathrm{J}]}\end{array}$ & $\begin{array}{c}G_{\mathrm{O}_{2}} \\
{[\mathrm{mmol} / \mathrm{J}]}\end{array}$ \\
\hline 1 & 0.355 & 0.108 & 0.314 & 0.199 \\
2 & 0.295 & 0.080 & 0.301 & 0.151 \\
3 & 0.275 & 0.040 & 0.295 & 0.125 \\
4 & 0.397 & 0.074 & 0.293 & 0.207 \\
5 & 0.376 & 0.073 & 0.274 & 0.191 \\
6 & 0.302 & 0.058 & 0.262 & 0.172 \\
7 & 0.315 & 0.044 & 0.309 & 0.181 \\
8 & 0.261 & 0.052 & 0.283 & 0.181 \\
9 & 0.395 & 0.032 & 0.298 & 0.185 \\
10 & 0.359 & 0.053 & 0.257 & 0.195 \\
11 & 0.365 & 0.074 & 0.326 & 0.178 \\
12 & 0.288 & 0.057 & 0.282 & 0.184 \\
\hline
\end{tabular}

We also calculated the ratios of the densities of the foams produced by cross-linking using gamma radiation and $\mathrm{EB}$. In the last column are the respective oxidation efficiencies for gamma rays and EBs.

The research indicates that an increase in the amount of added zinc oxide caused a reduction in the density of foam when cross-linked by EB radiation dose of $100 \mathrm{kGy}$. The opposite tendency was observed in foams that were obtained with Tracyl as a radiation cross-linking support. The lowest density of $0.04 \mathrm{~g} / \mathrm{cm}^{3}$ was obtained for the foam obtained from a mixture containing zinc oxide and Tracryl in a ratio of 2/1 (Sample 11, radiation dose of $100 \mathrm{kGy}$ ) or a ratio of $1 / 2$ (Sample 12, radiation dose of $60 \mathrm{kGy}$ ).

Generally, a higher efficiency of polymer oxidation corresponds to a lower density of the foam. Scanning electron micrographs (Figs. 1 and 2) allow the assessment of the internal structure of foams obtained by polyethylene cross-linking using gamma rays and EB. Radiation cross-linked foams were characterized by a heterogeneous outer surface. On one side, the foam 
a

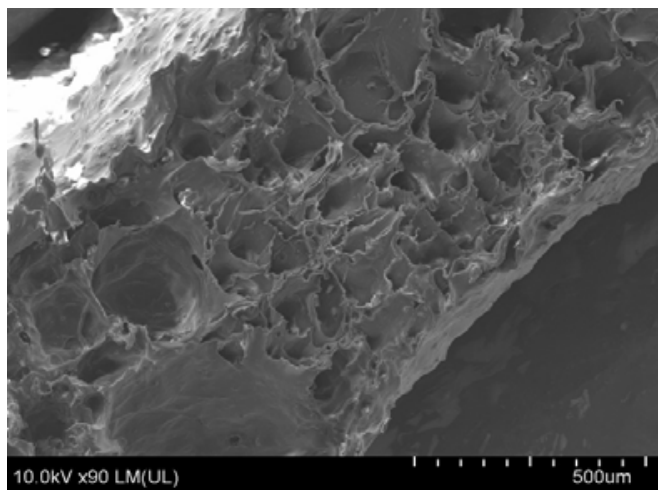

b

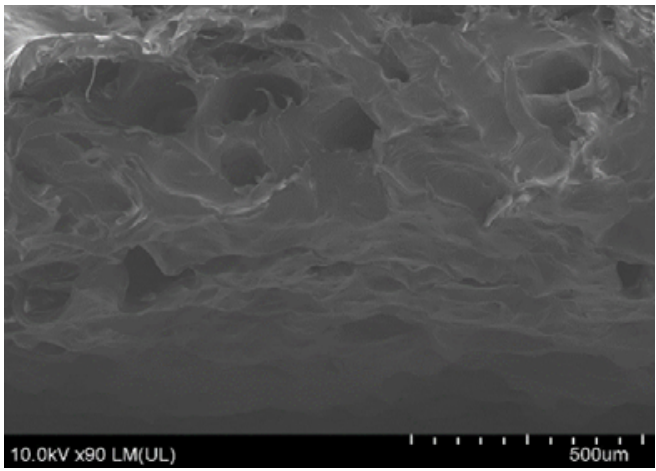

Fig. 1. Radiation cross-linked foams (Sample 4): (a) $100 \mathrm{kGy}-\mathrm{EB}$, (b) $100 \mathrm{kGy}-\gamma$ irradiation.

a

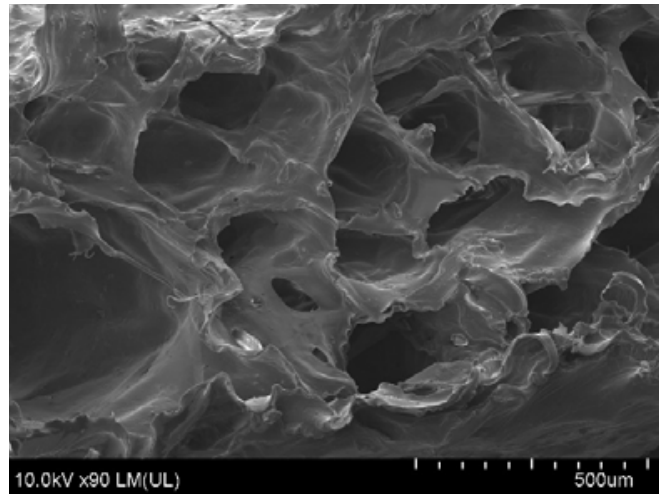

$\mathrm{b}$

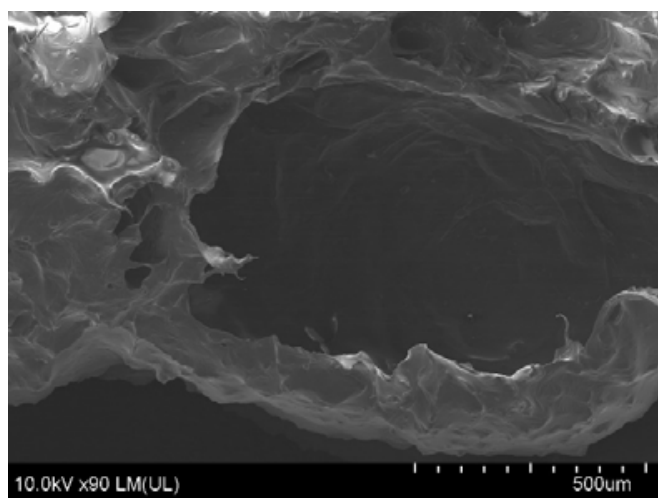

Fig. 2. Radiation cross-linked foams (Sample 4): (a) $60 \mathrm{kGy}-\mathrm{EB}$, (b) $60 \mathrm{kGy}-\gamma$ irradiation.

surface was smooth; on the other side, it was rugged and contained a lot of bubbles. The cell structure of the foams (Figs. 1 and 2) was heterogeneous with open and closed cells. Optical analysis supports the conclusion that the smallest pores (better cross-linked) were obtained using an EB.

To assess the degree of oxidation of the surface of the polyethylene film, DRS was used. Spectra were obtained only in the film irradiated with $100 \mathrm{kGy}$, relative to nonirradiated samples. Therefore, there was only a postradiation oxidation effect. The bands in the spectra of DRS are attributed to the products of oxidation of the polymer (Fig. 3). Table 4 shows the peak heights at the wavelength of $400 \mathrm{~nm}$ and the sum of the peak heights for the bands at wavelengths of 220, 400, and $500 \mathrm{~nm}$.

There is a good correlation between the oxidation yield obtained by GC and the intensity of bands in Table 4. Comparison of oxidation efficiency of polyethylene (GC) and the results of DRS

\begin{tabular}{rcccc}
\hline No. & $\begin{array}{c}\mathrm{DRS} \\
400 \mathrm{~nm}\end{array}$ & $G_{\mathrm{O}_{2}} / \mathrm{DRS}$ & $\begin{array}{c}\mathrm{DRS} \\
210+400+500 \mathrm{~nm}\end{array}$ & $G_{\mathrm{O}_{2}} / \mathrm{DRS}$ \\
\hline 1 & 0.23 & 1.16 & 0.39 & 1.96 \\
2 & 0.17 & 1.13 & 0.24 & 1.59 \\
3 & 0.13 & 1.04 & 0.19 & 1.52 \\
4 & 0.22 & 1.06 & 0.38 & 1.84 \\
5 & 0.20 & 1.05 & 0.31 & 1.62 \\
6 & 0.26 & 1.51 & 0.39 & 2.27 \\
7 & 0.14 & 0.77 & 0.22 & 1.22 \\
8 & 0.24 & 1.33 & 0.35 & 1.93 \\
9 & 0.23 & 1.24 & 0.34 & 1.84 \\
10 & 0.17 & 0.87 & 0.23 & 1.18 \\
11 & 0.16 & 0.90 & 0.21 & 1.18 \\
12 & 0.17 & 0.92 & 0.24 & 1.30 \\
\hline
\end{tabular}

the spectrum of DRS. Exceptions are Samples 10, 11 , and 12 , for which the amount of oxygen absorbed is much greater.

\section{Conclusions}

- Free radicals formed as a result of irradiation of polyethylene (hydrogen detachment) can chemically react with oxygen (present in the air) or recombine, with the formation of cross-links. Both phenomena (cross-linking and postradiation degradation) compete with each other. Generally, restriction of oxygen access results in increased cross-linking efficiency. The easiest way to limit the diffusion of oxygen into the polymer is to increase the radiation dose rate.

- The radiation dose rate has a significant effect on the properties of polyethylene foams. At a high dose rate (low oxygen diffusion into the polymer), a better cross-linked material was obtained. Using EB, foams with smaller cells were obtained and, as a result, a higher density of the material.

- For polyethylene radiation during the production of foams, high-power electron accelerators can be recommended. In comparison with chemical cross-linking by means of radiation technologies, we obtain foams with smaller cells and thus reduced thickness.

- The protective effect of aromatic antioxidants in the process of radiolysis of different types of mixtures is not clear. This will be the subject of further research.

- GC and DRS proved to be good analytical methods to observe the processes of postradiation 

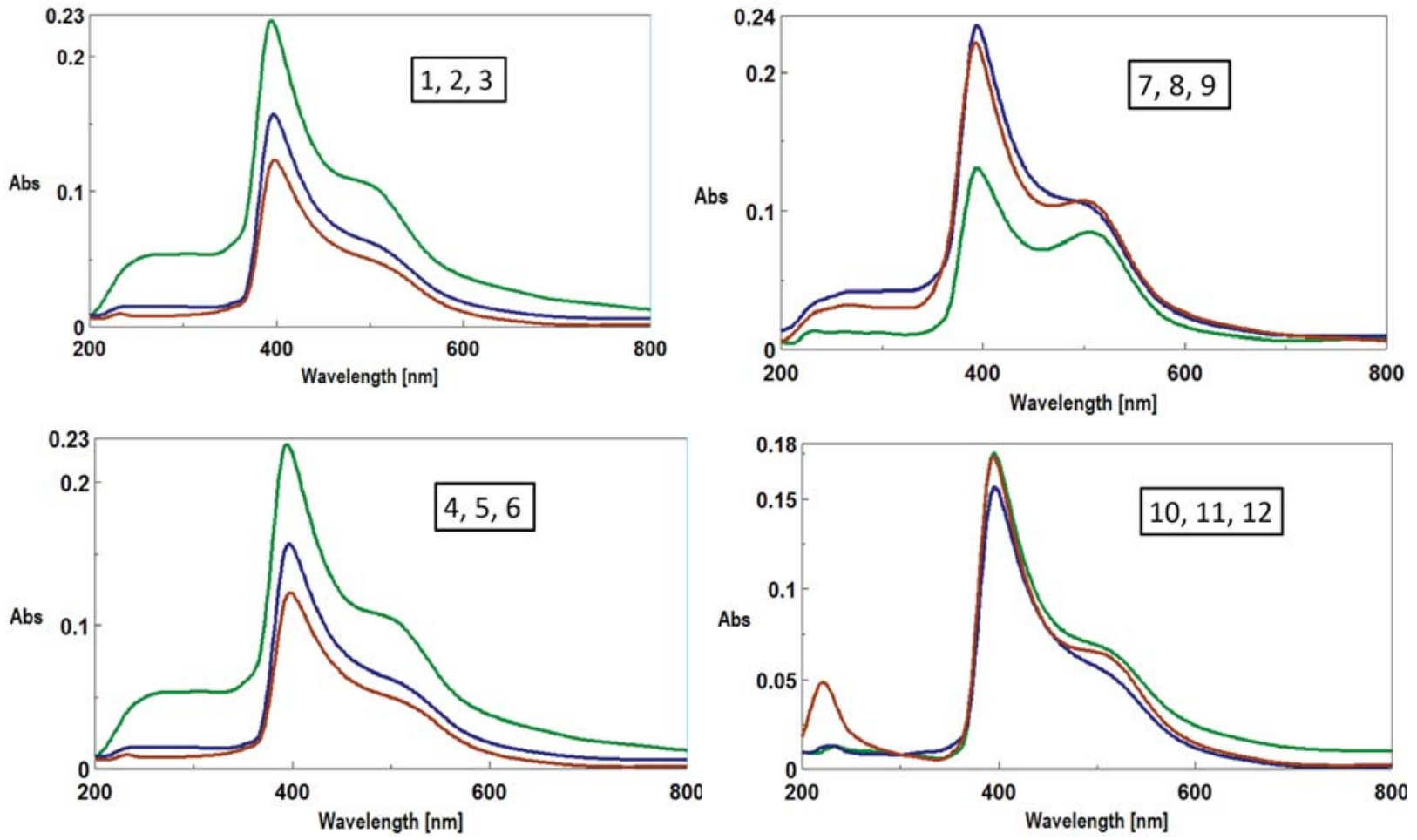

Fig. 3. Absorbent DRS spectra for Samples 1-12 irradiated with $100 \mathrm{kGy}$ in air. The bands in the DRS spectra are calculated from the top of the figure.

oxidation of polymers. In most cases, increasing the efficiency of absorbing oxygen correlated with the increase in the intensity of the bands in the DRS spectrum corresponding to the oxidation products of the polymers.

- The research also had a practical aspect. The study facilitated the choice of the optimal composition of plastic and the optimal irradiation conditions. The selection criterion was the density of the foam obtained.

\section{References}

1. Abe, S., \& Yamaguchi, M. (2001). Study on the foaming of crosslinked polyethylene. J. Appl. Polym. Sci., 79, 2146-2155.

2. Bo, Wang, Mouhua, Wang, Zhe, Xing, Hongyan, Zeng, \& Guozhong, Wu. (2013). Preparation of radiation crosslinked foams from low-density polyethylene/ ethylene-vinyl acetate (LDPE/EVA) copolymer blend with a supercritical carbon dioxide approach. J. Appl. Polym. Sci., 127, 912-918.

3. Stasiek, A., Raszkowska-Kaczor, A., \& Bajer, K. (2013). Wpływ obecności środka wspomagającego sieciowanie oraz zawartości środka porującego na właściwości polietylenowych pianek chemicznie sieciowanie. Prz. Chem., 92 (6), 1038-1041.
4. Raszkowska-Kaczor, A., Stasiek, A., Janczak, K., \& Olewnik-Kruszkowska, E. (2015). Chemically crosslinked polyethylene foams of limited flammability. Polimery, 60(4), 283-285.

5. Bik, J., Głuszewski, W., Rzymski, W. M., \& Zagórski, Z. P. (2003). EB radiation crosslinking of elastomers. Radiat. Phys. Chem., 67, 421-423.

6. Zagórski, Z. P., \& Kornacka, E. M. (2013). Radiation processing of elastomers. In P. M. Visakh, S. Thomas, A. K. Chandra, \& A. P. Mathew (Eds.). Advances in elastomers (Vol. 1, pp. 375-452). Berlin: Springer Verlag.

7. Głuszewski, W., Zagórski, Z. P., \& Rajkiewicz, M. (2014). Synergistic effects in the processes of crosslinking of elastomers. Radiat. Phys. Chem., 94, 36-39.

8. Zagórski, Z. P. (2003). Diffuse reflection spectrophotometry for recognition of products of radiolysis of polymers. Int. J. Polym. Mater. Polym. Biomat., 52, 323-333.

9. Głuszewski, W., Zagórski, Z. P., \& Rajkiewicz, M. (2015). The comparison of radiation and a peroxide crosslinking of elastomers. KGK-Kautsch. Gummi Kunstst., 15(11/12), 46-49.

10. Głuszewski, W., Zagórski, Z. P., \& Rajkiewicz, M. (2014). Protective effects in radiation modification of elastomers. Radiat. Phys. Chem., 105, 53-56.

11. Głuszewski, W., Zimek, Z., Kubera, H., Kozera, K., \& Abbasova, D. (2017). Paper radiolysis. Towaroznawcze Problemy Jakości, 50(1), 58-65. 